Thomas Daiber

\title{
LINGUAL PERFORMANCE AND ATTITUDE TOWARDS REGIONAL MOVEMENTS: SILESIA*
}

\section{Economic or cultural argumentation}

It is well known that since the 1980s the political importance of regional political movements in Europe has grown ever more and yet there exists a huge amount of mostly political and sociological investigations about the phenomenon. The majority of the authors seem to agree, that the regionalist movements should be viewed in relation to discrepancies between the respective national government and the supranational European level. A recent dissertation ${ }^{1}$ on regionalist movements in South Tirol shows to which extent national and supranational developments can foster regionalist tendencies. Decisions on a national level tend to neglect territories at the periphery of the respective national state ${ }^{2}$ and so possibly give rise to regionalist protests, motivated by "injustice felt". ${ }^{3}$ On the other hand decisions on the European level support regional actors because they are needed as partners in the realisation of the European measurements. The regionalist movement in South Tirol has gained its relative autonomy in an official acknowledged "European Region South Tirol - Tirol - Trentino" over a time span of approximately 25 years. As the starting point of the "European Region South Tirol - Tirol - Trentino" its official webpage names the year $1995^{4}$ when in Bruxelles

* I am grateful to Katarzyna Wiśniewiecka-Brückner, M.A. (University of Gießen), who helped me in understanding the "Silesian" quotations (remaining errors are mine, of course).

1 J. Oberhofer, Regionalismus als Herausforderung - Gesamtstaatliche Parteien in Südtirol und Venetien, Erlangen-Nürnberg: Diss. Phil. Univ. Erlangen-Nürnberg 2011.

${ }^{2}$ T. Zarycki, Politics in the periphery: Political cleavages in Poland interpreted in their historical und international context, "Europe-Asia Studies" 2000, Vol. 52, No. 5, p. 851-873;T. Zarycki, Four dimensions of the centre-periphery conflict in the Polish electoral geograph, [in:] Social Change. Adaptation and Resistance, eds. G. Kolankiewicz, G. Wieczorkowska, UCL Press, London 2001.

${ }^{3}$ W. Glatzer, Gefühlte (Un) Gerechtigkeit, "Śląski Przegląd Statystyczny" 2011, nr 9, p. 7-20.

${ }^{4}<$ www.europaregion.info $>$ 
an agency of the Tirol - South Tirol - Trentino-Region has been opened. An office in Bruxelles as the starting point for an European region - is there better a symbol for the process of regionalisation? Regionalist movements are a consequence of supranational developments in the European area.

While both national and European political decisions work nolens volens together in the emergence of regional movements it is seen that economic and political motivations don't play a dominant role in descriptions the inhabitants of the regions give of themselves. It goes without declarations of common political principles, ${ }^{5}$ if representatives of the autonomous Basque Country join the so called Silesian "March of autonomy" (Marsz Autonomii) which took place in Katowice on July $14^{\text {th }} 2012$. It surely is inappropriate to conclude that the supporters of the Silesian autonomy share with the Basque regionalist movement all inherent political approaches, for example a supranational approach to the conceptualisation of "Region". While several supporters of the Basque Country claim that regions which are today located within the boundaries of France should also be included in an autonomous Basque Country, similar claims - to my knowledge - aren't made by the supporters of the Silesian region. There are too many burdens of recent history that it would be possible to demand a supranational Silesian region which would allow for significant influence of the German (and of the rarely mentioned Czech) Silesian neighbourhood. While the German ele-

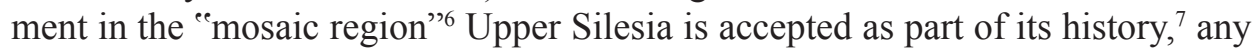
supranational conceptualization of Silesia is impossible to think. ${ }^{8}$ Due to economic and social differences and due to the fact that after World War II the polish speaking population in Lower Silesia has been significantly enriched by speakers from the former eastern regions of the Polish territory who weren't familiar with the Silesian dialect the notion of the region Silesia in Polish discussions mutually is restricted to its subregion "Upper Silesia" (Górny Śląsk). In history it was Upper Silesia which always had been the focus of separatist movements, even during the communist time of Poland, ${ }^{9}$ when people in Silesia partly identified itself more with Germany than with Poland. ${ }^{10}$

\footnotetext{
5 "w marszu uczestniczyli m.in. Katalończycy i reprezentanci Kraju Basków”; <wiadomosci. wp.pl>, published 14.07.2012.

${ }^{6}$ M.S. Szczepański, A. Śliz, Mozaikowy region etniczny i jego społeczne metamorfozy. Przypadek Górnego Ślaska, "Górnośląskie Studia Socjologiczne” 2011, Seria Nowa 2, p. 232-249.

7 P. Wróblewski, Miejsca symboliczne na Górnym Ślasku. Między "sacrum" a "profanum", “Górnośląskie Studia Socjologiczne” 2010, Seria Nowa 1, p. 133-145: St. Annaberg (Góra św. Anny) as a memorial place for Polish and German Silesians.

${ }^{8}$ Also in Germany, emigrants of Silesia aren't identified as Silesians, but as Polish, V. Wecker, Sprache und Identität im Kontext der Migration schlesischer Aussiedler nach Deutschland, "Studentische Arbeitspapiere zu Sprache und Interaktion 2009", Nr. 15, noam.uni-muenster.de/SASI. .

${ }^{9}$ Ibidem, p. 25.

${ }^{10} \mathrm{Ph}$. Ther, Die einheimische Bevölkerung des Oppelner Schlesiens nach dem Zweiten Weltkrieg. Die Entstehung einer deutschen Minderheit, „Geschichte und Gesellschaft“ 2000, Nr. 26, p. 407-438.
} 
The different regionalist movements in Europe are hard to compare because of different historical and political backgrounds. But all regionalist movements seem to share a fundamental ambiguity: regionalist movements on the one hand are driven by political and economic motivations, but one the other hand they argue in terms of culture or ethnicity which do not refer to economic reasons. While this, of course, is an unsettled impressionistic statement regarding "all" regionalist movements in Europe, it can be proven at least for the Silesian regionalist movement. An example would be the "Welcome Text" - only in English - published by the "Silesian Autonomy Movement" (Ruch Autonomii Śląska = RAŚ) on a heavily used "social network service" on the Internet:"11

We perceive our autonomy in similar way to Spanish autonomous regions or lands in Germany. [...] we believe that mature democracy in many European countries and USA has developed into political systems which maintain and highlight cultural differences within the regions what countries benefit from. [...] We want to provide regions more influence on creating the local law to replace slow, inflexible and not regions-oriented governmental decisions. We want our regions to be more decisive on how the taxes are spent by increasing their participation in taxes sharing and decreasing lion's share collected by central government now. We believe such actions will result in more efficient way of making decisions and therefore will upgrade the living standard of all the regions.

The text refers both to political and economic reasons on the one hand ("laws", "taxes") and to "cultural differences" on the other hand and is a good example for a two-folded rhetorical with unconnected to each other economic and cultural arguments.

The ambiguity of the regionalist movements also is seen when different explanations of region building are compared. Political and economics sciences in general say that regions tend to unify themselves because of "hard" economic reasons. While the supranational free market demands for individuality of each actor, these actors at the same time are interested in infrastructures which they can control by themselves. The result is the region as the regional market with regional producers and customers:

Monetary policy and political ideology complete themselves (in this way) to form a virtuous circle of regional integration: monetary policy pushes ahead with individual norms, which by themselves dissolve hierarchical structures and set free the individuals from their holistic-nationalistic shackles. (Collignon 2005, 12, italics original, translation Th. D.) $)^{12}$

It is fully rational to explain the emergence of regions under economic aspects. Especially Upper Silesia, suffering from political and economic changes since $1990,{ }^{13}$ which put the region out of the Polish focus for some time, is struggling

$11<\mathrm{http} / / /$ www.facebook.com/ruch.autonomii.slaska/info>; seen 03.12.2012.

12 "Geldwirtschaft und politische Ideologie ergänzen sich (somit) zu einem virtuous circle regionaler Integration: die Geldwirtschaft treibt individualistische Normativität voran, die ihrerseits hierarchische Strukturen auflöst und Individuen aus ihren holistisch-nationalistischen Fesseln befreit."

13 J. Wojnicki (Alternacja władzy w państwach Europy Środkowo-Wschodniej po 1990 roku, "Studia Politicae Universitatis Silesiensis" 2011, nr. 7, 115-133) refers the process of evolving democratic structures in different East European countries which during the time of their evolvement had a lack of stringent governmental decisions. 
to develop regional perspectives ${ }^{14}$ in relation to its history ${ }^{15}$ and in continuation of regional governmental reforms in all East European countries having become members of the European Union in 2004 and in 2007. ${ }^{16}$ Already the description of the economic problems of the specific Upper Silesian industrial landscape evokes the impression of a coherent territory - as does the description of texts of Silesian authors. ${ }^{17}$ On the other hand the self-description of the inhabitants in Silesia rarely touches the economical point of view but is based on notions of culture, language, ethnicity, or just feelings of being at home. To explain the difference between 'hard' factors like economy and power on the one side which stimulate regionalist movements and 'soft' individual and emotional reasons on the other side the European Union, although being a major factor in the emergence of regional self-consciousness, is supporting research on the individual motives of local inhabitants. In the framework of the project SPHERE there has done extended work about the individual motivation of Upper Silesian inhabitants, focussed on narratives of identity, ${ }^{18}$ visual representation of the industrial landscape, ${ }^{19}$ and emotional bonds to work places, ${ }^{20}$ to name just a few. ${ }^{21}$ From the point of view of sociolinguistics ${ }^{22}$ Silesian and Kashubian have already been put into the greater framework of Polish language politics. The following observations want to contribute to this "cultural" side of the double-folded regionalist arguments by having a look into

${ }^{14}$ A. Bartoszek, Demograficzne i kulturowe czynniki adaptacji do środowiska zbudowanego na Górnym Śląsk - postindustrialne potrzeby a wzorce zamieszkiwania, "Górnośląskie Studia Socjologiczne" 2011, Seria Nowa 2, p. 192-212.

${ }_{15}$ P. Wróblewski, Miejsca symboliczne...

${ }^{16}$ A. Czyż, Rozwój samorzadu terytorialnego w państwach Europy Środkowej i Wschodniej, "Studia Politicae Universitatis Silesiensis" 2011, nr 7, p. 134.

${ }^{17}$ D. Krzyżyk, Odzwierciedlenie języka i kultury regionu w śląskich pieśniach górniczych, "Z Teorii i Praktyki Dydaktycznej Języka Polskiego" 2009, nr 20, p. 152-165.

${ }^{18}$ P. Kulas, Nasze narracje regionalne, "Górnośląskie Studia Socjologiczne" 2011, Seria Nowa 2, p. 128-137.

19 P. Ćwikła, K. Łęcki, Świat przedstawiony Górnego Śląska od (soc)realizmu do realizmu magicznego - reprezentacje symboliczne regionu w obrazach, "Górnośląskie Studia Socjologiczne" 2011, Seria Nowa 2, p. 113-127.

${ }^{20}$ M. Gnieciak, Emocje i pamięć. Przyczynek do „geografii emocjonalnej” w ramach analizy wywiadów mieszkańców osiedli postrobotniczych w Będzinie i Rudzie Śląskiej, "Górnośląskie Studia Socjologiczne" 2011, Seria Nowa 2, p. 60-89; B. Słania, (A)spoteczność lokalna? Przemiany więzi społecznych na przykładzie dzielnicy Ksawera w Będzinie, "Górnośląskie Studia Socjologiczne" 2011, Seria Nowa 2, 90-102.

${ }^{21}$ Form more studies on Silesia see the first two volumes of "Górnośląskie Studia Socjologiczne".

${ }^{22}$ K. Wiśniewiecka-Brückner, Kleine Sprachen und kleine Kulturen in Polen - Kaschubisch und Schlesisch: Die Rolle der Sprache in der Darstellung und Konstruktion von Identität, „Konzeptualisierung und Status kleiner Kulturen. Beiträge zur gleichnamigen Konferenz in Dresden vom 3. bis 6. März 2008“, eds. C. Prunitsch, Sagner, München 2009, p. 265-276; K. Wiśniewiecka-Brückner, Polen (Rzeczpospolita Polska), [in:] Europäische Charta der Regional-oder Minderheitensprachen. Ein Handbuch zur Sprachpolitik des Europarat, eds. F. Lebsanft, M. Wingender, de Gruyter, Berlin-Boston 2012, p. 211-226. 
comments of non-professionals on issues regarding Silesian autonomy. What can the language use in internet comments tell us about the motivations of authors who use terms like "dialect" or "language" and how can the use of dialectal forms in these comments be understood as part of the argumentation?

\section{Comments on Silesia - a small corpus}

Already a cursory reading of postings on the internet shows that the question about the existence of a "Silesian language" is an important argument in claims pro or contra an autonomous region "(Upper) Silesia". To roughly estimate the weight of the language argument and to evaluate which linguistic terms are most frequently used in the discussion a "corpus" ${ }^{\prime 2}$ has been built ${ }^{24}$ out of editorial texts and their respective user commentaries found at the internet based news agency $<$ wiadomośći.pl $>$ by searching its archive for the name of the Silesian Autonomy Movement "Ruch Autonomii Śląska" (searched with quotation marks). It was aimed to get a text collection about "Silesian issues" with a significant amount of user comments of approximately 200.000 words. The articles have been manually collected in the order of their appearance starting from the most recent one. The collected 22 articles have appeared over a time span from April 04, 2011 until October 04, 2012. The articles are presented by the Internet publisher according to their "relevance" and it has not been tried to rearrange them in chronological order. One article ${ }^{25}$ has been left out, which has not been commented by users of the website, although being relevant to the Silesian theme; another three left out articles ${ }^{26}$ were accompanied by user comments but touched the Silesian theme only peripheral: two articles deal with the airplane crash in Smolensk, ${ }^{27}$

${ }^{23}$ I am fully aware that the texts that have been collected for this paper do not constitute a corpus in the sense of a balanced, annotated and designed corpus with regard to a special research question (A. Lüdeling, A corpus linguistics perspective on language documentation, data, and the challenge of small corpora, "Potentials of Language Documentation: Methods, Analyses, and Utilization" 2012, Vol. 3, p. 32-38, www.nflrc.hawaii.edu/ldc/sp03.), but can be considered as a small range corpus (A. Kornaiet al., Web-based frequency dictionaries for medium density languages, "Proceedings of 2nd Web as Corpus Workshop, European Chapter of the Association for Computational Linguistics (Org.)”, eds. A. Kilgarriff, M. Baroni, 2006, p. 1-8).

${ }^{24}$ The Internet texts have been collected on December 03, 2012.

25 "Czy zagłosują za przywróceniem autonomii Górnego Śląska?” (2011-06-28, 15:25).

${ }^{26} 10$ kwietnia - boję się tego dnia (2011-04-06, 09:18); O czym świadczy brak pomnika Lecha Kaczyńskiego? (2011.04.04, 09:40); Wszystkie partie zachowaty poparcie; tylko jednej spada (2011.04.03, 11:53).

${ }^{27}$ Th. Daiber, Sakralisierung im säkularen Diskurs: Ein Flugzeugabsturz als katastrofa, drama und tragedia, [in:] Sprachliche Säkularisierung (Westslawisch-Deutsch), ed. A. Nagórko, Olms, Zürich 2011, p. 103-124 (= westost-passagen. Slawistische Forschungen und Texte 13). 
the third is an opinion poll about Polish political parties amongst them also mentioning the RAŚ. The texts have not been touched in any way so it cannot be excluded that some misspelled tokens in the users comments go without mention; but the probability to misspell "gwara", "dialekt" or "język" is not too high, while unusual orthography, maybe due to technical reasons, like "jezyk" (46 times in the comments) has been taken into consideration. Word counting and alphabetical word ordering has been done using the program "AntConc" 28 .

The editorial texts consist of 16.585 tokens respectively 5184 "types", the user comments comprise 235.765 tokens respectively 40.848 "types", but these numerical values are only meant as an approximate overview and we will not draw any numerical conclusions. ${ }^{29}$ The term "type" should only be understood in the meaning of "word form", because AntConc does not identify morphological variations of the same word. The user comments have regularly cumulated if "Jarosław Kaczyński" has been one of the political actors named in the title of the editorial text. While an article about the RAŚ failing to receive a required number of supporters in order to nominate a candidate for a local assembly ('RAŚ bez poparcia na Śląsku Cieszyńskim" ${ }^{30}$ ) has attracted 4 users to comment, one of the articles on J. Kaczyński in behalf of his opinion about the RAŚ is accompanied by 1826 user comments. ${ }^{31}$ Because the aim of this paper is not a discourse analysis in order to identify "theme words", "key-words", different "actors" and "evaluating terms" ${ }^{32}$

${ }^{28}$ Version "3.2.4m" on Mac OS X 10.7. Name and version of the program used for simple word counting is worth mentioning because due to unicode input (Polish diacritics) and internal handling of orthographic details (capitals, hypens) programs differ in their output. Of course, pre-processing (like in B. Han, P. Cook, T. Baldwin, Automatically Constructing a Normalisation Dictionary for Microblogs, "Proceedings of the 2012 Joint Conference on Empirical Methods in Natural Language Processing and Computational Natural Language Learning. Association for Computational Linguistics" 2012, p. 421-432) would be an inappropriate measure in comparison to the small number of tokens.

${ }^{29}$ Text elements of the website unrelated to the subject like menus, links, or advertising adds have been stripped of, but some irrelevant information may not have been deleted. All duplicate postings were deleted which showed up when looking for postings containing "język [jezyk]", "gwara", "dialekt", "Śląsk-". Duplicate postings not containing these words may have remained. Quotations of the posting in this paper conserve their original orthography.

${ }^{30}<\mathrm{http}$ ://wiadomosci.wp.pl/kat,1329, title,RAS-bez-poparcia-na-Slasku-Cieszynskim,wid,13729533, wiadomosc.html $>(2011.08 .29,14: 25)$.

$31<$ http://wiadomosci.wp.pl/kat,1027191,title,Jaroslaw-Kaczynski-strzelil-samoboja,wid,13290411,wiadomosc.html> (2011.04.05, 16:56); the user comments are displayed on 67 different webpages. It should be kept in mind that the content management system of webpages is not infallible and sometimes may display the same comment at the end of a page and at the beginning of the next. Also not all comments nested in separate threads could be opened at the same time and saved to a file and surely some have been missed. In short: the numerical values given for the amount of user comments are to be treated as indications of rough proportions.

${ }^{32}$ Th. Daiber, Chernobyl after Fukushima. A layered corpus linguistic analysis of Polish internet comments, "Comparing Fukushima and Chernobyl: Social and Cultural Dimensions of Two Nuclear Catastrophes", eds. A. Graf, Th. Feldhoff, Conference in Frankfurt, March 2012, (in print). 
lexical frequency in a strict sense is not considered. The aim of the corpus is just to represent people's comments on Silesian themes regardless of the subject of the respective editorial text.

\section{Language terms as arguments}

According to the editorial texts of the news agency language arguments play only a very modest role in discussing the Silesian regionalist movement. In the editorial texts the word "language" is mentioned only two times in the context that the RAŚ wants the Silesian dialect to be acknowledged as a "regional language". One time a political scientist from the university of Silesia (Uniwersytet Śląski) is using the term "regional language" ("kwestia uznania śląskiego za język regionalny"), another time the political head of the RAŚ, Jerzy Gorzelik, is reasoning about the statistical poll of the Polish government (Narodowy Spis 2011) and a possible "distortion of the data regarding the question of nationality and, perhaps, language" ("zdeformowanych danych dotyczących kwestii narodowości i być może języka"). The term "dialect" ("dialekt") isn't used at all in the editorial texts, the term "subdialect" ("gwara") appears only two times and only in quoting advocates of the Silesian autonomy.

While language doesn't seem to be a major point in the official political rhetorical, the user comments on Silesian issues on the contrary often are based on the language argument. We will now have a look on the use of terms like "language / język", "dialect / dialekt" and "sub-dialect / gwara" in the user comments by describing the semantic extension of a language term and mentioning its typical collocations.

\section{1. (Everyday) speech / mowa}

Besides the idiomatic expression "it is spoken about = "tu jest mowa / mowa jest $0 . . . "$ "mowa" 33 as a linguistic term appears 11 times in the user comments and means "everyday non codified speech". ${ }^{34}$ The term appears in evident quotations of conceptual written texts (two quotations from a report on a statement of the Polish political party "Platforma Obywatelska" = 1), in pejorative (2) or neutral (3) meaning and also in the comment of a linguistically informed user, who mentions the use of the dual in the Silesian verbal paradigm (4):

${ }^{33}$ In the morphological variants: mowy (2), mowę (2), mowie (2), mowa (4), mową (1).

${ }^{34}$ With the exception of one user ( humorysta [2011.04.04, 10:07]) who mourns he had to leave school, because the Silesian teacher didn't understand his "pure Polish speech in written and oral form" ("czystej mowy polskiej. Mowy pisanej i mówionej"), where "mowa" exceptionally is used for "language". 
(1) mordy wy nasze [2011.04.05, 20:29]: [...] Dokument jest rządową opinią na temat ustawy nadającej mowie śląskiej rangę języka regionalnego. [...] Dodał, że mowa śląska nie jest językiem, a dialektem [...] (repeated by antyidiota [2011.04.06 08:27]

The document represents the governmental opinion on the theme of the legal act to give the Silesian speech the rank of a regional language. [...] He added, that the Silesian everyday speech isn't a language, but a dialect [...]

(2) . [2011.04.07 00:01] [...] ja nie życzę sobie czytać waszej małpiej mowy na portalu Wirtualna Polska

I don't want to read your monkey speech on the portal Wirtualna Polska ${ }^{35}$

(3) e.szakalicka $[2011.04 .08,11: 59][\ldots]$ ten naród [...] ze swoimi odrębnymi tradycjami, mową, kulturą ludową.

this nation $[\ldots]$ with their distinct traditions, speech, folk culture

(4) Mike [2011.04.05, 17:04] [...] Mowa śląska zawiera wiele archaizmów zapomnianych we współczesnym polskim. Tak jest z formą “przyjedźTA". Jeżeli mówimy “przyjedźTA”, oznacza, że mówimy do DWÓCH osób.

Silesian speech contains a lot of archaisms forgotten in common Polish. This is the case with the form "przyjedźTA". If we say "przyjedźTA" (= they two arrive), it means, we are talking about TWO persons.

In short, "mowa"is used to signify an oral variant of a language, lacking a normative description, and spoken by a regional population.

\subsection{Dialect / dialekt}

The term "dialect/ dialekt" appears 10 times in the user comments. The commenters don't obey a semantical difference between the terms "dialect / dialekt" and "sub-dialect / gwara" (cf. also 3.3):

(5) adaswd [2012.09.18, 23:20]: [...] Co najwyzej macie gware slaska do jezyka polskiego, ktorego wasi przodkowie nie mogli sie sami nauczyc wiec dodali sobie niemiecki dialekt.

You have your Silesian sub-dialect additionally to the Polish language, which your elders weren't able to learn by themselves and so mixed it up with a German dialect.

In comment (5) only in a speculative manner a semantical difference could be constructed between a now existing Polish sub-dialect / gwara and a once existing German dialect / dialekt. Rather both terms are used as synonyms like in the following comment which evidently has been pasted from the lemma "Ślązacy" in the Polish edition of an online encyclopaedia (wikipedia):

(6) Kociewiak [2011.04.05, 12:26] [...] Posługują się oni zespołem śląskich gwar lub dialektów języka polskiego o różnym zakresie wpływów języka niemieckiego i czeskiego

$35 \quad$ Virtual Poland $=<$ wp.pl $>$, a popular internet service. 
They use a complex of Silesian sub-dialects (gwara) or dialects (dialekt) of the Polish language to a different extent of influences of the German and Czech languages.

While the distinction between the terms "dialect / dialekt" and "sub-dialect / gwara" could only be expected in a linguistically informed article the collocations of "dialect" are noteworthy for our purpose, because "dialect" occurs regular in the context of "language at border", "language under the influence of another language". Cf. above (5) or:

(7) pol [2011.04.05, 15:52] Polska Piastowska była od początku państwem jednolitym etnicznie. [...] Germańskie związki plemienne [...]wchodziły do historii [...] z własnymi nazwami etniczno-językowymi,własnymi dialektami graniczącymi z odrębnymi językami.

The Poland of the Piasts has been from its very beginning an etnical uniform state. [...] The German tribal bonds [...] went into history [...] with their proper ethnic-lingual names, their proper dialects which share the border with distinct languages.

(8) technol72 [2011.04.04, 17:39] Także te osoby które mówią że Śląsk od zawsze należał do Niemiec MÓWIĄ NIEPRAWDĘ !!! [...] Chcą Ślązacy posługiwać się dialektem Śląskim proszę bardzo, pielęgnować swoją kulturę proszę bardzo nikt tego nie zabrania, a zwłaszcza Konstytucja RP. Do tego autonomia nie jest wcale potrzebna!!!!

Also the people who say that Silesia always had belonged to Germany TELL LIES!!! [...] Go ahead, let the Silesians use the Silesian dialect, go ahead, let they care for their culture, nobody hinders it and above all (not) the Polish Constitution. For this (goal) autonomy is absolutely not necessary!!!!

While comments (7) and (8) point to dialect as a phenomenon at the border of a territory, the next comment of user "linguist" (językoznawcza) hypotesizes the fate of the Polish language in a anglo-lingual dominated Europe as a "dialect":

(9) Językoznawca [2011.04.05, 14:48] [...] starannie uczysz się angielskiego i przymuszasz to tego także swoje dzieci, do wobec wejścia do Unii Europejskiej, to ten język zapewne stanie się językiem literackim europejskiej naszej Ojczyzny, a polski dialekt zapewne pozostanie w użyciu nadal po wsiach i leśnych przysiółkach?

You carefully learn English and you also force your children to do it, because related to entering the European Union, this language will for sure get the literary language of our Motherland, and the Polish dialect for sure will stay in use in villages and in wooded wasteland?

Also in the rather fictional context of example (9) dialect is conceptualised as a form of speech at the border, spoken not in the centre of a territory but in its uncultivated regions. It is this collocation of "dialect" which is also dominant in the use of its synonym "gwara"".

\subsection{Dialect / gwara}

The term "gwara" (literally "sub-dialect") appears - as mentioned above (3.2) - synonymous with "dialect", at least the comments don't give reason to look for any semantic difference. The stem "gwar-" appears 34 times as a noun and 3 times 
as an adjectiv; the type-token-ratio in comparison to "mowa" (3.1) and "dialekt" (3.2) points to the productivity of "gwara" as the counterpart to "language / język". While "mowa" can be used as an insulting term for the speech of other people (example 2), "gwara" also shows up in connection with possessive pronouns of the first person. Besides of its neutral meaning "gwara" typically occurs with the specification "Silesian". Noteworthy is also the possible plural form which can refer the fact that "Silesian" is a language term referring to three dialects of three (Polish, Czech, $\mathrm{German}^{36}$ ) different languages, which sometimes is also mentioned in the corpus.

\begin{tabular}{|l|c|}
\hline \multirow{3}{*}{ gwara (34) } & gwara śląska (14) / gwary śląskie (1) \\
\cline { 2 - 3 } & śląska gwara (1; cf. example 10)/ śląskie gwary (1; cf. example 6) \\
\cline { 2 - 2 } & moja gwara (1) \\
\cline { 2 - 2 } & nasza gwara (1) \\
\cline { 2 - 2 } & swoja gwara (2) \\
\cline { 2 - 2 } & gwara 13 \\
\hline gwarowy (3) & \\
\hline
\end{tabular}

The word order "gwara śląska" is dominating and specifies the meaning. Generally spoken, in Polish the postposition of the adjective related to its noun signifies a categorial meaning, while an adjective in anteposition to its noun signifies a property ${ }^{37}$ A word order "polski język" is just not to be found and felt to be ungrammatical. The following commenter uses the possibilities of word order delicately:

(10) tomek 78 [2011.04.05, 16:56]: Znam znakomicie śląską gwarę i znam również język polski Wy już nas nie rozumiecie.

I know excellent the Silesian dialect [śląska gwara] and I know to the same extend the Polish language [język polski]. You never will understand us.

In comment (10) two identically formed propositions differ in the position of adjectives in relation to the accusative object; the semantic distinction expressed by word order is relevant as the distinction "the dialect which is typical for Silesia" vs. "language with the characteristics of Polish". The great majority of the commenters, however, put the adjective "Silesian" postponed to its noun which shows that "gwara śląska" has reached the rank of a categorisation. It is not a dialect with certain lingual properties ("słowiánska gwara" = "slavic dialect", 1 times in the corpus), but it is a language existing as a dialect (e. g. "gwara wielkopolska" = "Greater Polish dialect", 1 times in the corpus). The use

${ }^{36}$ For the Czech variant of "Silesian" see J. Balhar, Skladba lašských nářeči, "Česká nářečí" 1974, č. 7), , for the German variant W. Jungandreas, Zur Geschichte der schlesischen Mundart im Mittelalter: Untersuchungen zur Sprache und Siedlung in Ostmitteldeutschland [zuerst 1937], Steiner, Stuttgart 1987.

${ }^{37}$ Prefixed = accidens ("akzidentelle Eigenschaft"), postfixed = proprium ("wesenhafte Eigenschaft"), but the tentative word-order can be inverted by pragmatic and idiomatic reasons, U. Engel, D. Rytel-Kuc, Deutsch-polnische kontrastive Grammatik, Bd. 2, Julius Groos, Heidelberg 1999, p. 925 f. 
of the adjective "Silesian" in combination with "dialect / gwara", but also in combination with "language / język" gives the commenters the possibility to graduate sensibly between Polish, Silesian and the only regional language of Poland which is officially acknowledged, Kashubian:

(11) walczyk [2011.04.05, 12:44] Język kaszubski nie jest gwarą w żadnym stopniu, śląski język jest gwarą wywodzącą się z języka polskiego. Takie jest moje zdanie.

The Kashubian language isn"t a dialect in no sense, the Silesian language is a dialect derived from the Polish language. This is my impression.

(12) all [2011.04.11, 00:20] A do tego nawet nie mówi gwarą (bo kaszubski czy śląski to nie języki, a gwary). Pozdrawiam. Polska dla Polaków, a nie RAŚ-istów.

And above all he (Donald Tusk) doesn't speak in dialect (because Kashubian or Silesian aren't languages, but dialects). Greetings. Poland to the Polish, not to the RAŚ-ists.

The commenter of example (11) displays the semantic difference between a classified language by means of postponing the adjective ("język kaszubski”, "język polski") and a locally restricted dialect by means of anteposition of the adjective ("śląski język"). Such sensible graduation, of course, is not regularly found in the comments: the commenter in (12) denies Kashubian the status of a codified language and word order, of course, should not be overestimated in interpreting the user comments.

Also interesting is a look at the context, "gwara" is used in. Searching in the range "10 words to the left and to the right periphery" the context of "gwara" is dominated by the types "Silesian / śląski" (13 times) and "language / język" (10 times). This collocations reflect the main point of the argumentation: Is the Silesian dialect/gwara a language of its own? The question is discussed in comparison to the Polish language (6 times) or to the German variety of dialects (4 times). Beyond that there is a special semantic field "gwara" is regularly found in, namely allusions to diachronicity (2: archaizm, 1: relikt, 1: staropolski). A proper dialect is conceptualised as the historical variant of a codified language (cf. also examples 5-7):

(13) Ziga [2011.04.06, 01:08] [...] Nie ma śląskiego języka - jest gwara śląska - archaizm języka polskiego z naleciałościami niemieckimi.

There is no such thing like a Silesian language - there is a Silesian dialect - an archaism of the Polish language with German traces.

(14) roro [2011.07.02, 14:39] [...] że gwara śląska to piękne narzecze staropolskie zachwaszczone germanizmami !

[...] that the Silesian dialect is a beautiful Old Polish idiom overgrown by Germanisms.

The argument "dialect is archaic" could be named a discourse pattern, because it occurs both with opponents (13) and supporters (14) of the Silesian "dialect". The term "archaic" isn't primarily related to the age of a lingual expression, because then the approximately 1500 years old Polish language itself would be 
archaic, too. "Archaic" always means a lingual expression which once has existed in the normative language but has survived only in non-standard variations. So, both commenters (13 and 14), either deprecating or praising the Silesian dialect, share the same discourse assumption: Polish is the norm.

Having no sufficient great corpus at hand it would be too dangerous to draw more conclusions about the use of "gwara". But in comparison to the context the term "language" is found in (see 3.4) it can be stated that "gwara" and "dialekt" as synonyms for "dialect" tend to the semanic tinting "lingual entity at a territorial or temporal border".

\subsection{Language / język}

Of course, by far the most used term for lingual entities is "language / język". Combining with a prefixed adjective the term "language/ język" can have the meaning "natural language", but in most cases it displays the meaning "codified standard language". The term "język" (135) resp. "jezik" (34) occurs 169 times (only 7 times in the plural form) and additionally appear the adjectival derivations "językowy" (6) and "jezykowy" (7). Within the context of "język" the most noticeable semantic field is covered by lexical items like "topographic names / nazwy miejscowości" (4 +3) and "people / naród" resp. "nation / narodowość" (6). Other items like "region / regionalny" (4) can occur as well. But the most important context of "language" is its connection with "nationality" and/ or "ethnicity":

(15) mot [2011.07.02, 13:22] Ślązacy to taka niby nacja, która nie ma nawet swojego języka.

The Silesians are quasi a nation, which does not even have its own language.

(16) i tyle [2011.04.21, 12:59] Narodowość śląska? Nie ma" narodu śląskiego" - bo nie ma języka śląskiego. Jest tylko gwara śląska, więc jak naród może mówić gwarą?

Silesian nationality? There is no "Silesian nation" - because there is no Silesian language. There is only a Silesian dialect, and how can a nation speak a dialect?

(17) Jan [2011.04.21, 12:44] Nie ma narodowości śląskiej, bo Śląsk nigdy nie był narodem, tak samo jak wielkopolska, Kaszuby itd. Ślązacy to polska ludność etniczna, gdyż ich język należy do grupy słowiańskiej, a nie germańskiej.

There is no Silesian nationality, because Silesia has never been a nation, like Greater Poland, the Kashubians and so on. The Silesians belong ethnical to the Polish people, like their language belongs to the Slavic, not the Germanic group.

(18) 11 [2011.04.21, 12:29] Proponuję aby w kwestionariuszach spisowych każdy wpisywał swoją narodowość pochodzącą od nazwy regionu. Ja wpisałem u siebie narodowość mazowiecką i takiż język używany w domu.

I suggest that in questionnaires everybody notes his nationality related to the name of the region. I have written "Masurian nationality" and this language is used at home. 
(19) bart [2011.04.21, 12:27] Nie ma narodowości śląskiej, kujawskiej, mazowieckiej, góralskiej, tylko jest polska [...] nie ma czegoś takiego jak język śląski, jest tylko gwara wykorzystująca polską gramatykę, składnię i słownictwo, różniąca się jedynie wymową i pewnymi naleciałościami.

There is no nationality Silesian, Kujawian, Masurian, Goralian, only Polish. [...] There is no Silesian language, there is only a dialect which uses the Polish grammar, declination and lexicon, distinct only by articulation and certain traces.

The existence of a Silesian, non-polish identity is bound to an ethnic difference between Polish and Silesians which is proved by the existence of a distinct Silesian language. Because ethnicity is bound to a specific language only the existence of a language seems to give a good argument for autonomy. If languages are similar then ethnicity is similar, too:

(20) K.K [2011.04.05, 16:34] Oczywiście ,tak jak nie ma narodowości Słowackiej, Czeskiej itd. bo to są tylko Słowianie mówiący bardzo podobnymi językami.

Naturally, so there is no nationality Slovak or Czech and so on, because there are only Slavs speaking very similar languages.

The pairs "language and nationality" and "nationality and ethnicity" can mutually be used synonymous, and not only both terms in each pair, but also both pairs as a whole. Language is a sign for nationality or ethnicity, and because language points to both nationality or ethnicity, both nationality and ethnicity become mutual synonyms. To deny claims of autonomy means to deny that the Silesian idiom could be named a language.

\section{Performance of language: godać and godka}

From the lexical stem "god-" the Silesian idiom ${ }^{38}$ has derived terms for "language" = "goda / godka" and for "to speak" = "(po)godać". The term "god(k) a" is 17 times used both by opponents and supporters of a Silesian language. Some comments are aggressive in referring to WWII and the Nazi regime in Silesia because of heavy lexical German influence on the Polish Silesian dialect, some comments seriously use Silesian dialectal forms to express their Silesian identity. All comments can be divided into three groups of lingual strategies to support their resp. arguments. The first strategy is to substitute single words in a Polish text with their Silesian counterpart, a strategy which (by chance?; cf. 5) only has been observed in comments of opponents to the Silesian autonomy. The second strategy is to write the whole comment in Silesian, which has been done by both supporters and opponents to the Silesian autonomy. The third strategy is code shifting between Polish and Silesian, which also accompanies texts pro and contra the Silesian autonomy claim but seems to be done only by authentic speakers of the Silesian dialect.

${ }^{38}$ For the translations I have consulted an online dictionary of the Silesian dialect $<$ godka.pl/ slownik-slaski-gwara-slownik-jezyka-slaskiego.html>. 


\subsection{Lexical substitution $=$ alien elements}

Examples for the strategy of lexical substitution are found mostly with the verb "godać" (substituting Polish "mowić") or the noun "Hanys" (the common nickname for "Silesian", derived from the German proper name "Hans"), which both are common Silesian markers.

(21) Europejczyk [2011.04.05, 17:01] Prostackie uproszczenie. Godanie gwarą śląska jest takie same jak mówienie góralską czy mazurską czy galicyjską, jest mówieniem po Polsku. Jesteś Polakiem ze Śląska ot i wszystko. A jak chcesz rozrabiać to reszta społeczeństwa szybko ci pokaże gdzie Twoje miejsce. Po wojnie się zaczęło? A za Adolfa to ci pasowało ? Byłeś w Hitlerjugend?

Foolish simplification. Speaking the Silesian dialect is the same like speaking the Goralian, or Masurian, or Galician everyday speech, it is speaking in Polish. You are a Polish from Silesia and this is all. If you want to kick up a fuss then the rest of the society will quickly show you Your place. Do you long for war? You'd like to be Adolf? Have been in the Hitlerjugend?

(22) Ginter [2011.06.28, 14:59] Gdy przyznasz się kim jesteś, stracisz rodzinę? [...] A farbowany gorol udający Hanysa godoł publicznie że odcinają się od mniejszości niemieckiej.

Why would you lose your home, if you say, what you are? [...] But the camouflaged Goral who behaves to be a Hanys, said publicly that (the Silesians) stem from the German minority.

Comment (21) displays expressis verbis the popular assumption that the Silesian Autonomy Movement is operated by remote control of Germany. To support this claim the dialectal word "godanie" is used as a variant of the Polish non-standard word "mowenie" in the meaning "everyday speech / mowa" (see also 3.1). The dialect form "godanie" is a lexical marker for Silesia, like "Adolf" and "Hitlerjugend" are lexical markers for Germany. The markers of Silesia and Germany appear in the Polish text like alien elements and perform the argument: the claim of autonomy for Silesia is an alien, possibly German intervention into Polish affairs.

Comment (22) puts in its Polish text the common nickname for Silesians "Hanys" (from the German proper name "Hans") and the verb "godać" to characterise a well-known propagator of the Silesian Autonomy Movement, who is supposed to be of no Silesian origin, but to exploit the movement for his own purposes by pretending to speak the Silesian dialect. Comment (22) uses Silesian markers to perform the false pretension by showing how easily it is done. In both comments (21 and 22) Silesian dialect forms show up in a surrounding Polish text like alien elements and this lexical substitution performs the content of the argument. Silesians are disguised Germans resp. Polish with disguised intentions.

Similar, the use of Silesian dialect forms as alien elements in a Polish text can also have ironical effects, like

(23) MǍźller [2011.08.21, 16:35] @Ślązak prawdziwy [...] no godej ,prawdziwy Slązak walczyl z Niemcami [...]

@ True Silesian $[\ldots]$ but say, a true Silesian fought with the Germans $[\ldots]$ 
(24) spoza Śląska [2011.08.08, 09:01] Polacy na Górnym Śląsku: czas zacząć uczyć się "godki" i zgodzić się na bycie "Ślązakiem" drugiej kategorii bez "rodowodu", albo pakować manatki. Wyrazy współczucia...

To the Polish in Upper Silesia: it is time to begin learning "godka" and to agree to be a "Silesian" of secondary category without "genealogy", or to pack your staff. Expressions of pity...

Comments (23 and 24) use the words "godać" respectively "god(k)a" ironically. Example (23) as a request to tell the truth is at the same time the offer, to do it in Silesian if the addressee is unable to use Polish. ${ }^{39}$ Example (24) admonishes the Polish population in Upper Silesia to learn the dialect in order to integrate into the region Silesia although a native Polish speaker always will be depreciated in Silesia because of the lack of a German genealogy. The key words (name of the dialect, name of the Region, concealed hint to German background) are given in quotation marks, singled out as foreign elements and at the same time profiled as rhetorical elements whose reference to phenomena in an extra-lingual world is questionable.

Lexical substitution can also be done in the form of a contrast like in the following aggressive example (there would be more on both sides):

(25) Kolka [2011.07.02, 14:06] Schnittlauch â€“"szczypiorek / śl. Sznitloch, Tomate - pomidor - śl. tomata. No i gdzie tu język śląski trochę niemca trochę gówna trochę Polski to jest właśnie język śląski wg RAŚ, weźta tę swoją reisentasche wsadźta pod bundeslade i wołajta my chcemy krzynka piwa. RAŚowcy zasmarkane

Schnittlauch Polish szczypiorek / Silesian sznitloch. Tomate - (pol.) pomidor - silesian tomata. So where is this Silesian language, a bit of a German, a bit of shit, a bit Polish, this truly is the Silesian language according to RAŚ, take your Reisentasche, sit under the Bundeslade and cry: we want a box of beer. Snot-nosed Raśisten.

Example (25) displays confronts Polish words with their Silesian counterparts to make the hostile ("German") and impure ("shit") influence on Silesia visible; Silesian is characterized as a mixture of (false) German and Silesian ${ }^{40}$ elements.

Lexical substitution is a way to not just utter, but to perform the argument: Silesian words are an alien element in a Polish context. If the performance of alien elements supports the meaning of the words $(21+22)$ it works as an intensification

39 The formulation "walczyć z Niemcami" = "to fight with the Germans" could be understood as "fight on the side of" or "fight against".

${ }^{40}$ In example (25) the verbal forms with the suffix -ta (weźta, wsadźta, wołajta) are used like an imperative, while they in fact are old aorist forms - a prominent feature of Silesian ("Die meisten Dialektismen wurden bei der Bildung der Vergangenheitsformen notiert" in I. Rohfleisch, Sprachsituation und Sprachverhalten in Teilen des heutigen Oberschlesiens, Diss. phil. Univ. Heidelberg. (gedruckt als Manuskript: Berlin: dissertation.de 2001), Heidelberg 2001, p. 129). The German word "Bundeslade" refers exclusively to the Ark of the Covenant (pol. Arka Przymierza) of the Old Testament; the author obviously means "Bundestag" (building in Berlin) but mixes it up with a rare word acquired only during religious education in church or school. Finally, the author plays the usual phonetic game with the akronym for the Silesian Autonomy Movement "RAŚ" as if it be an abbreviation for "racist" with the German ending (Raśist-en) instead of the Polish (raśist-y, raśistki, raśisc-i). There is more knowledge of German and less of Polish with this author than the meaning of his words conveys. 
of the argument. If the performance of alien elements is done against the meaning of the words it will produce an ironical effect $(23+24)$. Alien elements may directly serve as proof for hostile intentions of the Silesian autonomy movement, and, absurd enough, against the existence of a Silesian language (25). In all cases, the lingual strategy of lexical substitution or lexical contrasting is used only by opponents of the Silesian autonomy, because it is a performance of strangeness, a performance of the reproach that the Silesian Autonomy Movement is under remote control of an alien (Germany, some comments also speculate about Russia [cf. example 32]) power.

\subsection{Silesian texts $=$ performance of difference}

Some comments are written throughout in a / the Silesian dialect. ${ }^{41}$ This is observed both with supporters and opponents to the Silesian Autonomy Movement. Mostly the use of Silesian dialect forms is done in order to perform that the idiom although claiming to be an own language cannot claim uniqueness because it can be performed by non-Silesians as well. To this aim opponents of the Silesian Autonomy Movement write throughout in a Silesian idiom. This user with the nickname "A Pole" imitates the self-description of the Silesian people:

(26) Polak [2011.04.13, 15:21] JO NIE POLOK, JO ŚLĄZOK [...]

I am not a Pole, I'm a Silesian

Some authors are found, who write the whole comment in Silesian like the user "Silesian":

(27) Ślunzok [2011.08.16, 16:19] Jo rzech je ze Slunska i jo rzech je dumny. Jo wala trzi flaszki gorzały w tydniu i jo sie chca łodautonomić som nie wia czamu, ale tak godają to powtarzom

${ }^{41}$ It is not the aim of this paper to judge if a given comment reflects the actual lingual behaviour of its author resp. his ability of lingual imitation. This would require a fine grained description of the Silesian dialect and its variants. E.g. comment (27), clearly ironical about Silesian, uses "rzech" as present tense, not as proper aorist, but gives correctly "chca" instead of Polish "chcę" as one of the main characteristics of the Silesian idiom (I. Rohfleisch, Sprachsituation ..., p. 97). Relatively to the assumed linguistic competence of the authors also "false friends" between Polish and Silesian have to be interpreted. E.g. comment (28) uses the word "Goral", which means in Polish a "Goral" (a person from a mountain region in Poland), but refers in Silesian to every person who is "not a Silesian". The dialect of Upper Silesia is not fading, but changing, more and more being identified on phonological and lexical level, while the syntax becomes undistinguishable from the Polish one (cf. M.L. Kucharczyk, Zur sprachlichen Situation in Oberschlesien. Master's thesis, Univ. München, München 2010, p. 81; for the pragmatic level see T. Kamusella, Language: Talking or trading blows in the Upper Silesian industrial basin?, "Multilingua" 2011, no. 30, p. 3-24). In this paper, the statement that a text is written in Silesian means that the author tried to give the whole text a Silesian appearance in contrast to only rendering some words in their Silesian form (like 4.1). 
I say that I am from Silesia and I say that I am proud..$^{42}$ I want three bottles of schnapps every week and I want to autonomize myself, I don't know why, but how they say I repeat it.

Here the ironical effect is emerging from the content, not from mixing of Polish and Silesian words (like in 4.1). This and the next example show that the use of dialectal forms does not allow to infer the political opinion of the author respectively his identity as Polish or Silesian:

(28) Qpa [2011.04.05, 16:36] Śląsk [.] Dyć głupa trzo, żeby takie dyrdymały godoć. Jo jezdem Gorol . Ale mom śwagra Hanysa, (konował po prawdzie aleć ludzki człek) ale chyba się do tej Autonomii przepiszę. Bo z tymi "ojcami Narodu" to już "wytrzymać nie idzie". To ja już wola chodzić za Hanysa niż za Gorola, jak Hoffman (Słowianin po byku) lub jego pryncypał. Fedrować nigdy nie fedrowałek, ale byłek roz na grubie w Zabrzu. Fyr.

It needs a fool to say such stupidities. I am not a Silesian. But I have a brother-in-law Hanys (quack doctor, as he is, but a considerate man) and probably I will support this Autonomy. Because these "fathers of the Nation" it is "impossible to bear". I already vote to follow a Hanys and not a Non-Silesian, like Hoffman [i.e. Adam Hoffman] (a Slav like a bull) or his leader [J. Kaczyński]. They didn't mine one single coal, but one time have been in the mine in Zabrze. Fu.

User "Opa" (German for "grandfather", frequent in Silesian dialects) displays disagreement with the Polish politics (especially with prominent figures of the opposition party) therefore supporting the separatism of Silesia although not being a Silesian himself. The user imitates in his comment the Silesian dialect and performs the making of an artificial identity he is arguing for.

The same use of the Silesian dialect as an identity marker is observed mostly in shorter comments like (29 and 30):

(29) starzyk [2011.04.08, 12:21] jo popra bo fest godajom

I support it, because they are speaking strong.

(30) Szlonzok [2011.04.04, 11:37] Godo Kobita prowda

The woman speaks the truth.

There are also longer comments like (31 and 32) which show the use of the Silesian dialect as a performance that the author belongs to this region, but this can be done both as support (31) or as rejection (32) to an autonomy claim:

(31) punkowiec [2011.04.04, 13:33] Nie był na tej lekcji... [...] Jarosław chyba niy boł w budzie bo mioł ała w tyn dzień, a nyi mioł kumplików to tyż nie mioł fto mu hefta do dom pożyczyć, co by sie lekcje som zrobił. A rechtorka godała, że Ślonzoki nie chcieli być w Niemcach ino w Polsce i o to sie prali w Powstaniach i za tym głosowali na Plebiscycie. A być Ślonzokiem to ni ma gańba!

He has not attended this lession... Most probably Jarosław didn’t attend school that day because he had an "aua" [expression of illness, Germanism], and he had no friends and so had nobody to bring him the notes from the class at home, that he could learn the lesson by himself. The principal said, that the Silesians didn't want to be neither in Germany nor in Poland and fought for that in the Resurrections and voted for that in the Plebiscite. To be a Silesian is no shame!

42 The formulation alludes to the formulation "I'm Black and I'm Proud", once refrain of a pop song and then a major slogan in the African-American movement. 
(32) ecik [2011.04.26, 15:36] Jo jes hanys, ale tyn cały RAŚ, to jes, podug mie - robota mośków. Kryncom swoje geszefty, jak zowsze - na moncyniu u innych. Uni chcom przejonć Szlunsk, ale przeca nie dla Niymców, a tak naprowde, dla mosków. Godom wom! I Kuc dlo mnie to tyz jest mosiek. Kumpel od michnika. Zoden prowdziwy Szlunzok, Hanys - nie zadołby sie z tym...

I am a Hanys, but this whole Silesian Autonomy Movement is - in my eyes - a work of the "Moscovits". They do their business, like always - by revolting others. They want to take over Silesia, by far not for the Germans, but for the Moscovits. This I tell you! Kuc [Polish movie director] also is a Moscovit to me. Close friend to Michnik [former dissident, now editor of a Polish daily newspaper]. No real Silesian, no Hanys would spend time with such people...

Writing whole texts in the Silesian dialect is not bound to any side of the political options but is used as a performance, either to show the imitability of the Silesian dialect as an argument against regional autonomy, or to perform the Silesian dialect as an obvious marker of difference resp. different identity.

\subsection{Code switching $=$ authenticity}

Code switching in the context of this paper means that some texts switch from Polish to Silesian mostly at the end of their arguments. This strategy seems to be taken up only by authentic Silesian speakers regardless of their opinion against (33) or pro (34) a Silesian autonomy; I was unable to find a switch from Silesian to Polish, but only observed the switch from Polish to Silesian at the very end of the comments, like in the following examples:

(33) gośc [2011.04.05, 21:29] [...] a co do powstańców... generalnie z hanysów głownie byli to lumpy i chachary!!! tak mi starka godali.

[...] with regard to the insurgents ... in general from the side of the Hanys most of them were bums and hooligans. So the grandparents told me.

(34) hanys [2011.07.02 14:27] fałsz, obłuda i zakłamanie to cały Kaczyński. Powie wszystko i wszystkim w zależności z której strony wieje wiatr aby tylko pozostać przy korycie. [...] Żadyn gorol, krawaciorz czy medalikorz niy bydzie mi godoł co mom robić a tym bardzij taki dziod jak Kaczyński

Lie, hypocrisy and insincerity that is the whole Kaczyński. I tell it everywhere and to everybody that he will always take his stand at the trough in relation to the direction the wind blows. [...] No Non-Silesian, with a tie or with medaillons, can tell me what I have to do and the more not an idiot like Kaczyński.

Comments (33) and (34) are written throughout in Polish but add one or more sentences in Silesian. Comment (33) shows the words "starik / starka" which mean "grandfather/ grandmother" in Silesian (instead of Polish "dziadek / babcia"). The author uses the dual, which is a main feature of the Silesian dialect, in this case "starka" = "(the two) elders = grandparents". Comment (34) argues in a rough tone against the prominent leader of the Polish opposition party and adds a Silesian sentence at the end stating that he may not receive any or- 
ders from Non-Silesians. Both examples aim at a similar effect: stressing an argument against or in favour of the Silesian autonomy by showing that the speaker is intimately involved in the issue he is speaking about. Code switching is used as a marker of authentic knowledge.

\section{Commenting the comments}

This paper aims to show that the language argument serves as the main point in the argumentation against or in favour of Silesian autonomy. By analysing the semantics of linguistic terms for "everyday speech" (mowa), dialect (dialekt / gwara), language (język / goda) and the performance of the Silesian dialectal features two things appear to be most important:

First, the notion of dialect as opposed to a language is affected either by the association that a dialect is spoken at the border of a language territory or by the feeling that the dialect is a somewhat archaic form of the standard language of a territory. Both arguments agree in the notion of a dialect as being at the border of space and time. The term "language" is often associated with the notion of ethnicity and nationality, being a broader frame for categorization than dialect. A linguistic definition of language and dialect, of course, is not found, but the use of both terms reveals how language users feel about standard and variation. We can conclude that not the existence of a dialect is the stimulus to form a regionalist movement but the regionalist movement, as usual emerging at the border of a given territory, finds powerful support in accentuating a given dialect as a marker of territorial and historical difference in relation to the centre of the territory. This may explain to some extend why political arguments in favour of separation usually are split into two main lines: one line of mostly economic arguing, and one line of additional cultural arguing using mostly linguistic impressions to express the dissent with the centre of the territory. Mainly the observation of an "archaic" dialect serves as an argument in favour of a historical based separate identity of the given dialectal community.

Second, the performance of lingual elements has three main strategies, which confirm the observations already extend in sociolinguistics.

The first strategy is lexical substitution that is occasional replacing of lexical items of the standard language with their dialectal counterparts. This strategy serves the purpose of profiling dialectal elements within the context of a standard language as alien elements with the connotation of a foreign power who controls the separatist movement of the dialectal territory and with the association of impure elements within the pure language of the majority. Lexical substitution is meant as a pejorative language use, only found by authors who oppose the claim of autonomy for the given dialectal territory. Lexical substitution is known to be 
a characteristic feature of the non-dominant language ${ }^{43}$ within a bilingual territory. Using lexical substitution as a pejorative dialect performance is a means to remember the social uncomfortable situation of the Polish speaking people in the biresp. multilingual territory Silesia once has been.

The second strategy of performing lingual elements consists in writing a whole text in the non-standard language. This strategy is used by both supporters of and opponents to the autonomy of the dialectal territory. The opponents use the strategy to prove that the dialect in question can be handled by speakers of the standard language as well which shows that there is no need to separate the dialectal territory from the main territory of the standard language. The supporters of autonomy use their dialectal texts as a performance of their separate identity. On both sides the strategy aims to explore the mutual difference between lingual communities.

The third strategy consist in the unidirectional code switching from the standard language to the dialectal form which has been observed exclusively at the end of the texts. Like the second strategy also code switching is not attached to a certain political stand towards the question of autonomy, but seems to be used only by speakers of the given dialect. The strategy is mainly aimed as an attestation that the speaker is authentically involved in the issues of the dialectal territory he is writing about. The third strategy emphasises authenticity, as such being a common means in speaker's choices between an official (standard) language of a territory and a familiar language related to personal contact, familiarity and individual credibility. Dialect here is used as the language of proximity and gives additional emotional value to the argument. ${ }^{44}$

The lingual features of the user comments show, that the users, being far away from a linguistic view on the subject, display their intuitive knowledge about language and lingual communication by the use of linguistic terms (3) and reproduce lingual behaviour, known from actual oral communication in bilingual societies, in electronic written form (4). The lingual behaviour, which sometimes is performed very deliberately, serves as a support for the resp. argument, but is, besides pejorative language use which is, of course, attached to a certain point of view, in most cases not attached to a possible political opinion regarding separatist movement.

43 "Dieses Verfahren der Lexemsubstitution (italics i. O.) ist [...] in besonderer Weise typisch für die Entwicklung der nichtdominanten Sprachen unter den Bedingungen des fortgeschrittenen Bilingualismus", G. Bellmann, Slavoteutonica. Lexikalische Untersuchungen zum slawisch-deutschen Sprachkontakt im Ostmitteldeutschen, "Studia Linguistica Germanica" 1971, Bd. 4, p. 30.

${ }^{44}$ Cf. for example Rohfleisch (Sprachsituation ..., p. 199) about motivations for the use of dialect. Narodowy Spis (Narodowy spis powszechny ludności i mieszkań 2011. Raport z wyników, Główny Urząd Statystyczny: Warszawa 2012, p. 108) shows the importance of Silesian as the language used at home (509.000 Silesian speakers) in contrast to the regional language Kashubian (106.000 speakers); J. Kijonka-Niezabitowska, (Po prostu Ślązacy, "Górnośląskie Studia Socjologiczne" 2010, Seria Nowa 1, p. 93-113 discusses the outcome of the Narodowy Spis. 